\title{
8
}
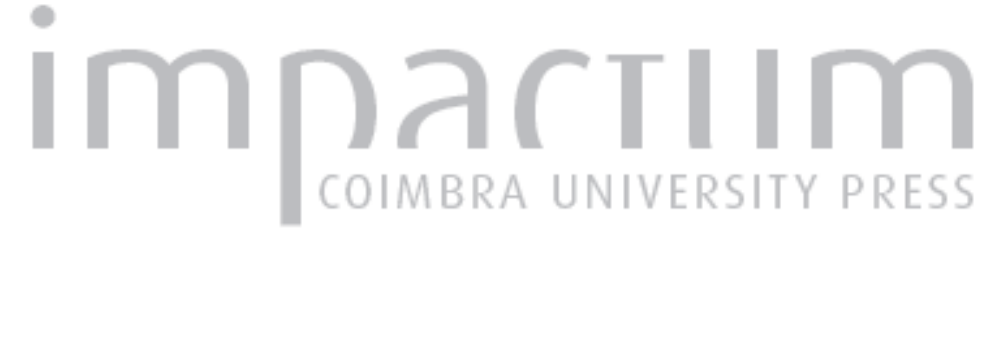

\section{Threatening disaster or mastered risk? A geo-historical approach of flood risk ir urban area: example of Mulhouse (France)}

\author{
Autor(es): $\quad$ Martin, B.; Ansel, R.; Drescher, A.; Guerrouah, O.; Glaser, R.; Riemann, \\ D.; Vitoux, M.-C.; Vogt, S.; With, L.
}

Publicado por: Associação Portuguesa de Riscos, Prevenção e Segurança

URL

persistente:

URI:http://hdl.handle.net/10316.2/36110

DOI:

DOI:http://dx.doi.org/10.14195/1647-7723_17_21

Accessed : $\quad$ 26-Apr-2023 14:51:27

A navegação consulta e descarregamento dos títulos inseridos nas Bibliotecas Digitais UC Digitalis, UC Pombalina e UC Impactum, pressupõem a aceitação plena e sem reservas dos Termos e Condições de Uso destas Bibliotecas Digitais, disponíveis em https://digitalis.uc.pt/pt-pt/termos.

Conforme exposto nos referidos Termos e Condições de Uso, o descarregamento de títulos de acesso restrito requer uma licença válida de autorização devendo o utilizador aceder ao(s) documento(s) a partir de um endereço de IP da instituição detentora da supramencionada licença.

Ao utilizador é apenas permitido o descarregamento para uso pessoal, pelo que o emprego do(s) título(s) descarregado(s) para outro fim, designadamente comercial, carece de autorização do respetivo autor ou editor da obra.

Na medida em que todas as obras da UC Digitalis se encontram protegidas pelo Código do Direito de Autor e Direitos Conexos e demais legislação aplicável, toda a cópia, parcial ou total, deste documento, nos casos em que é legalmente admitida, deverá conter ou fazer-se acompanhar por este aviso.

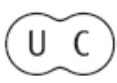




\section{territorium}

Riscos, Sociedade(s) e Segurança

Revista da Associação Portuguesa de Riscos, Prevenção e Segurança 2010 
THREATENING DISASTER OR MASTERED RISK? A GEO-HISTORICAL APPROACH OF FLOOD RISK IN URBAN AREA. EXAMPLE OF MULHOUSE (FRANCE) ${ }^{1 *}$

B. Martin (1)

CRESAT, Université de Haute Alsace, Mulhouse brice.martin@uha.fr

R. Ansel (1); A. Drescher (2); O. Guerrouah (1); R. Glaser (2); D. Riemann (2); M.-C. Vitoux (1); S. Vogt (2); L.With (1) (1) CRESAT, Université de Haute Alsace, Mulhouse (2) IPG, Albert-Ludwigs-Universität Freiburg i. Br.

\section{RESUMO}

O Plano de Prevenção dos riscos de inundação na bacia do Ill revela que a cidade de Mulhouse (França) - está quase totalmente fora de perigo de inundações. Esta situação parece ser o resultado da construção de um importante canal de derivação durante a segunda metade do século XIX. Para avaliar a sua eficiência incontestável, adoptamos uma abordagem histórica e geográfica sistémica e em diferentes escalas com o objetivo de contextualizar a evolução das inundações devastadoras e do sistema de proteção. Estes trabalhos foram realizados no âmbito do programa francoalemão TRANSRISK, financiado pela ANR e pela DFG

Palavras chave: riscos de inundação, geohistória, impacto antrópico, abordagem sistémica.

RÉSUMÉ

Le Plan de Prévention des risques d'inondation dans le bassin de l'lll révèle que la ville de Mulhouse (France) est presque totalement à l'abri des inondations. Cette situation apparaît comme le résultat de la construction d'un important canal de dérivation dans la seconde moitié du XIXème siècle. Pour évaluer son indéniable efficacité, nous avons adopté une approche géohistorique multiscalaire et systémique afin de contextualiser l'évolution des inondations destructrices et du système de protection. Ces travaux ont été conduits dans le cadre du programme franco - allemand TRANSRISK, financé par l'ANR et la DFG.

Mots-clé: risques d'inondation, géohistoire, impact anthropique, approche systémique.

\section{ABSTRACT}

The Prevention Plan against Flood Risks in the III Basin reveals that the city of Mulhouse (France) is almost entirely free from flood nuisance. This situation appears to result from the building of an important diversion canal for the III river during the second half of the 19th century. To improve the undeniable efficiency of the canal, we adopt a historical and geographical perspective at different scales in order to place the devastating floods as well as the urban and river system of protection in a broader context. Those results proceed from the studies carried out within the framework of the French-German program TRANSRISK, financed by the ANR and the DFG.

Key words: flood risks, geohistory, human impact, systemic analysis.

$1^{*} \mathrm{O}$ texto deste artigo corresponde à comunicação apresentada ao V Encontro Nacional e I Congresso Internacional de Riscos e foi submetido para revisão em 26-07-2009, tendo sido aceite para publicação em 16-04-2010.

Este artigo é parte integrante da Revista Territorium, n. ${ }^{\circ} 17,2010$, C Riscos, ISBN: 0872- 8941. 
What is the situation regarding the risk of floods in Mulhouse?

\section{Mulhouse and the III}

A "sous-préfecture" of the department of the HautRhin, Mulhouse with its suburbs including over 220.000 inhabitants is situated in the upper basin of the III (Fig.1). Issuing from the hills of the Sundgau, that river flows through Mulhouse after collecting the waters of the Largue and then proceeds to drain the plain of Alsace with its main cities (Colmar and Strasbourg) before flowing into the Rhine, having covered a distance of $223 \mathrm{kms}$ (Tab. I).

That river is of the torrential type upstream from Mulhouse is characterized by frequent floods resulting from the heavy rains in the autumn and the spring (the floods of April-May 1983), and chiefly the milder weather with the thawing of the winter snow. But that phenomenon is mostly to be feared above Mulhouse on account of the contribution of the streams from the Vosges, as shown by the spectacular floods of February 1990. For those various reasons, all the communes of the Haut-Rhin bordering the III have been the object

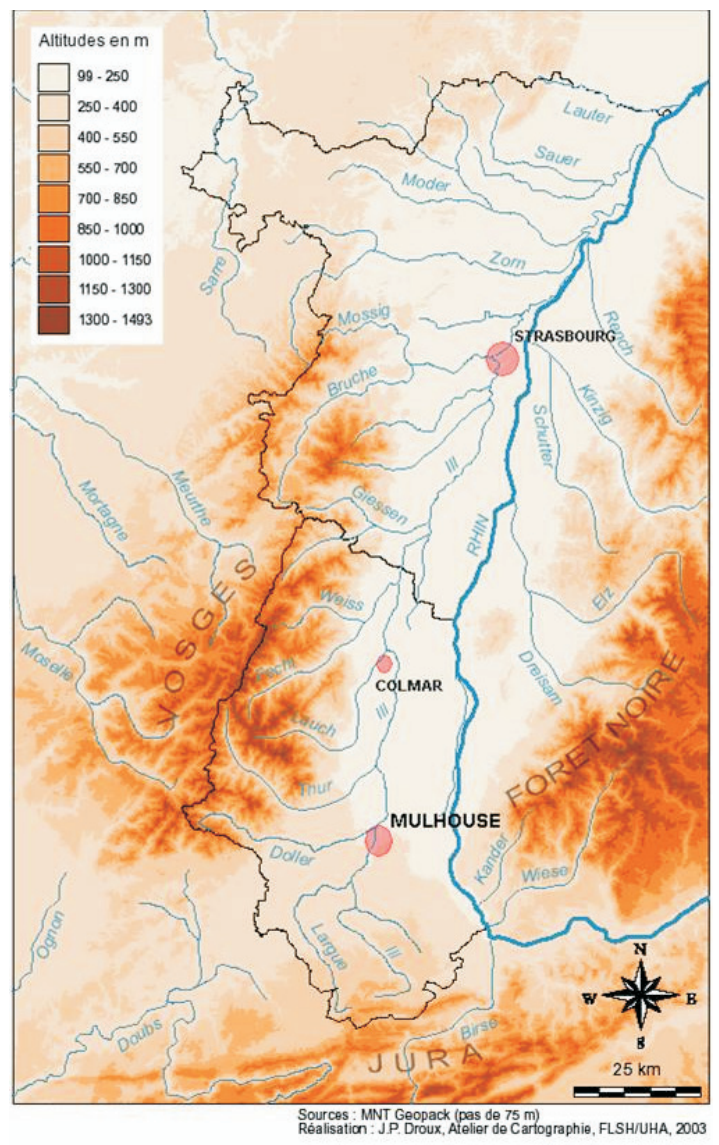

Fig. 1 - Location of Mulhouse on the IIl.
TABELA 1 - Hydrological characteristics of the IIl.

\begin{tabular}{|l|l|}
\hline Collecting area & $4760 \mathrm{~km}^{2}$ \\
\hline Length & $223 \mathrm{~km}$ \\
\hline Altitudes & $130-620 \mathrm{~m}$ \\
\hline Average flow & $58 \mathrm{~m}^{3} / \mathrm{s}$ \\
\hline Wave height & $398 \mathrm{~mm}$ \\
\hline
\end{tabular}

of a common statutory procedure of PPRI (Plan for the Prevention of the Risks of Floods) also including the communes of the basin of the Largue, and some tributaries of the III in the Vosges (Thur, Lauch, Fecht).

The PPRI of the Ill and the history of the floods

On the 27th of December 2006, the Plan for the Prevention of the Risks of Floods (PPRI) of the basin of the III was approved at the end of a procedure that had begun in... 1997 ! Whereas nearly one half of the communes involved had (unsuccessfully) manifested their opposition to the proposal of mandatory zoning with zones declared unfit for development, it was accepted without demur by the city of Mulhouse. The obvious reason was that the territory of the communes is practically immune to the risk of inundation in case of a general flood (Fig.2). True, the floods taken into account for the elaboration of the PPRI (1983 et 1990) had not caused significant damage in Mulhouse, and neither had the other occurrences of the overflooding of the III in the course of the 20th century, "within living memory". If one goes a little further back in time, however, the archives reveal that the town was extensively flooded by the waters of the III in 1852 (Fig.3) (Guerrouah; Martin, 2007). Besides, looking into the records of the decrees of "natural disaster", one sees that Mulhouse suffered damages caused by "floods and mudslide" on 7 occasions between 1987 and 2002.

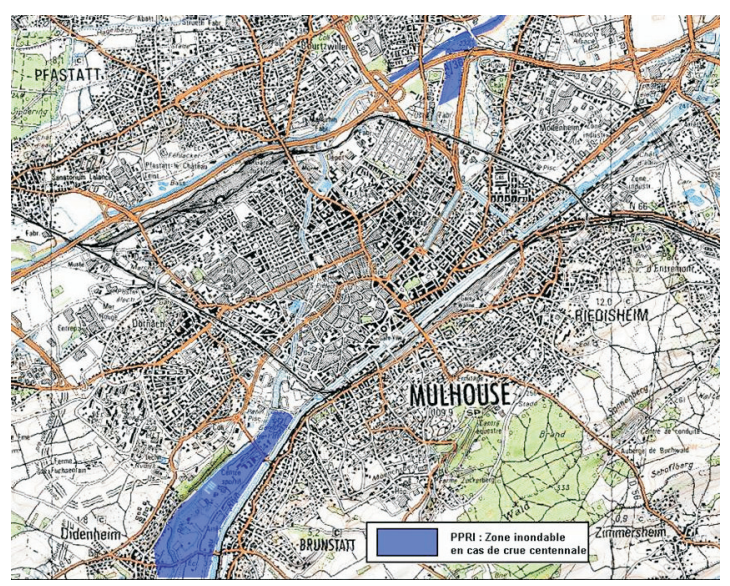

Fig. 2 - The area liable to flooding in Mulhouse, as defined in the PPRI of the III, and approved in 2006. 


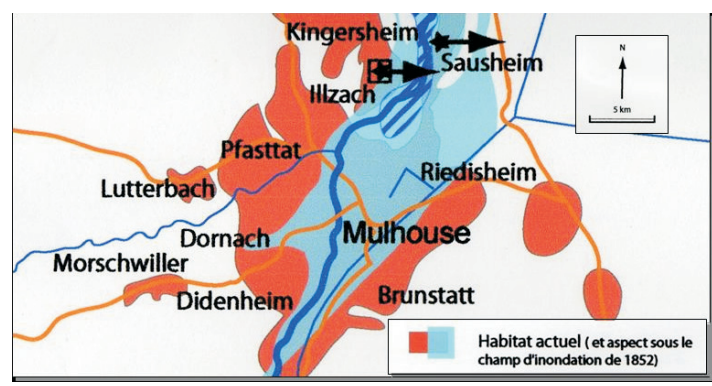

Fig. 3 - The area flooded in the proximity of Mulhouse during the flood of 1852 .

Obviously, there is a discrepancy between the official zoning and the reality of the risk of flood such as it appears at the present time, and even more if its evaluation extends over a long period, not just the last 20 years. Hence, one can raise several questions about how effectively the risk has been taken into account:

- Are we confronted with a climatic chance factor, namely the absence for more than one century of conditions facilitating the occurrence of a damaging flood, resulting in a gap in the collective memory and the underestimation of the risk by the PPRI?

- Has there been an evolution of the vulnerability of the city to floods between the $19^{\text {th }}$ century and the present? Or, more precisely, has some work been done to achieve greater security? In that case, the evaluation of the risk by the PPRI could be considered as correct.

- But how, then, can we interpret the occurence of events justifying the decree of a natural disaster due to "flooding and mudslide"? Do we have here secondary phenomena, arising outside the area defined, or another type of flooding?

The hypothesis of a climatic accident can hardly be retained, since one finds records for some fifteen instances of damaging floods in the basin of the Ill since 1852. After that date, however, considerable work was completed in Mulhouse, with the digging of the diversion canal of the IIl (Guerrouah; Martin, 2007).

\section{The city made safe through the diversion canal}

The diversion canal, intended to preserve the city from the floods, is a broad trench, running SW-NE through Mulhouse and dividing the city into two parts (Fig. 4).

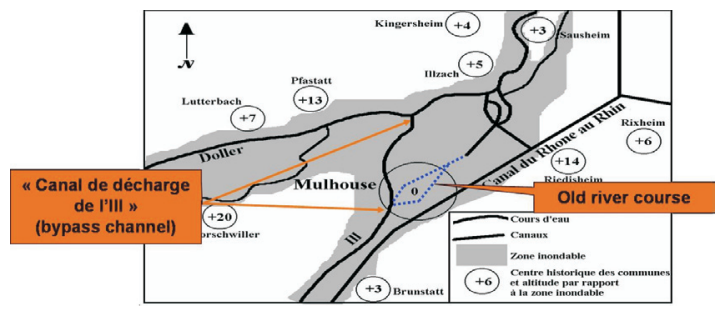

Fig. 4 - Modifications of IIl river in Mulhouse.
The idea of the canal was conceived in 1831, following a petition addressed to the Mayor on the initiative of some citizens exasperated by the repeated inundations. Unlike the neighbouring communes, which were not exposed to the floods, Mulhouse was situated on the swampy area at the confluence of the III and the Doller (Fig. 4). While the site is obviously suitable for military defence, it became a liability at the time of the Industrial Revolution for what was about to grow into the city of the hundred chimney stacks. The growth of the French Manchester was conditioned by the suppression of the areas liable to flooding for the protection of the factories and housing estates (MARTIN; Vitoux, 2003). Although a commission had met as early as 1833 to study the implementation of the project, the actual work was only begun in 1846, after many vicissitudes, under the pressure of the industrialists (ANSEL, 2008). The first canal was completed in July 1852 (Fig.5). No later than in September, however, a flood caused damages to the works and inundated the town. Another flood in 1860 finally persuaded the town council to carry out some improvements of the canal, which were completed in 1867 , and provided the town with a reasonably efficient protection. But the citizens had to wait till 1905 (Fig. 5), with the completion of the work undertaken under German administration (correction of some minor problems, the roofing over of a section of $1 \mathrm{~km}$ ) to have the full benefit of the canal with its spectacular dimensions (Photo. 1) such as it exists today (ТАB. II).

What we now have to do is to assess the true efficiency of the canal in the fight against the floods from the time it was built to the present day.

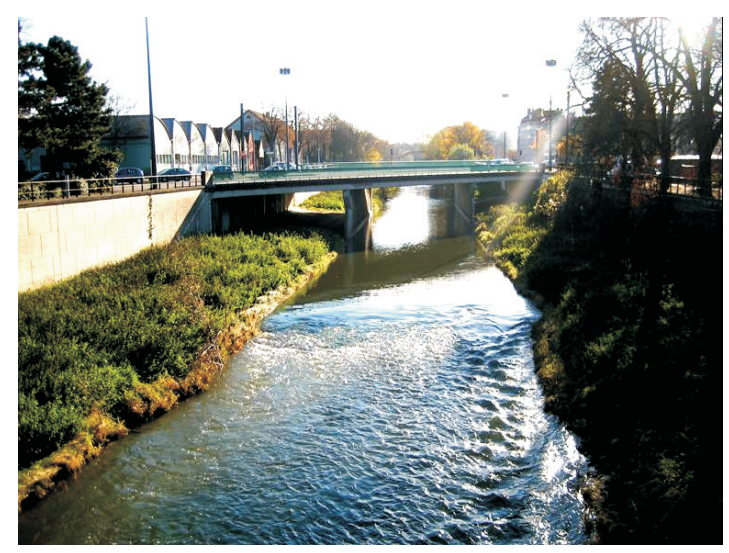

Photo 1 - The diversion canal of Ill in Mulhouse.

TABELA II - Dimensions of the diversion canal of the Ill.

\begin{tabular}{|l|l|}
\hline Length & $3,5 \mathrm{~km}$ \\
\hline Width & $40 \mathrm{~m}$ (approximately) \\
\hline Depth & $5 \mathrm{~m}$ (approximately) \\
\hline
\end{tabular}




\section{Evaluation of the protection against the floods}

\section{A comparative study of the historic floods}

On the basis of research in archives from different sources, we have undertaken to take an inventory of the historic floods in the basin of the III and then classify them on a scale of 3 levels of damage (Tab. III). Two separate chronologies are proposed, in order to compare the evolution of the number and intensity of the damaging floods, respectively in Mulhouse and in the rest of the III basin (Fig. 5).

\section{An interpretation of the chronology of the floods}

The comparison between the two chronologies proves to be very instructive for the evaluation of the process of increasing safety from the risks of flood for the city of Mulhouse, owing in particular to the role of the diversion canal. Its construction has an impact on random effects (an indirect influence on the dynamics of the floods) and vulnerability, through the protection it is supposed to offer and the urbanization that attends its completion. Indeed, we note that down to 1860 there is a perfect symmetry between Mulhouse and the rest of the basin as to the number and intensity of the floods. So, the efficiency of the diversion canal has only become manifest very progressively.
What is even worse is that its lack of efficiency during the first period $(1876,1895)$ has been the cause of more important floods in Mulhouse than in the rest of the Basin. That result is surprising, but logical, for in less than one century the population of the city increased from 8.000 to more than 100.000 . There was a huge demand for building land, and the urbanization (factory buildings and housing estates) was carried out in parallel with, and even in anticipation of the construction of the canal. And the new districts, working-class and industrial, developed on land liable to flooding, were those that proved highly vulnerable owing to the weaknesses of the early versions of the canal. Conversely, after the year 1905 when the final version of the canal was completed, Mulhouse appears clearly marked off from the rest of the Ill basin, with fewer and above all less damaging floods. So, there is no question of a lapse in the long-term memory of the floods, and the fact is that those who were on the scene of the risk have assimilated the reality of a greater protection against the perils of the river.

What then of the 7 decrees of "natural disaster" due to "floods and mudslide" occurring between 1987 and 2002 [1] ? A close study of the events proves that they are in no way the result of a flood of the III, but are a different phenomenon, mostly occurring in summertime, to which we shall return more in detail in the final part.

The higher frequency of damaging floods in the course of the last decades (if we leave Mulhouse aside) reflects the size of the demand for land and the current urbanization

TABELA III - Criteria used to classify inundations.

\begin{tabular}{|c|c|c|c|}
\hline Level & Classification & Primary indicators & Secondary indicators \\
\hline 1 & $\begin{array}{l}\text { Smaller, local } \\
\text { flood }\end{array}$ & $\begin{array}{l}\text { Little damage, f.e. fields and } \\
\text { gardens, roads close to the } \\
\text { river, etc. }\end{array}$ & Short flooding (hours, one - two days) \\
\hline 2 & $\begin{array}{l}\text { Above - average, } \\
\text { supra - local flood }\end{array}$ & $\begin{array}{l}\text { Damages on buildings and } \\
\text { constructions related to the } \\
\text { river : bridges, dams, mills ; } \\
\text { water in the buildings }\end{array}$ & $\begin{array}{l}\text { Severe damages on fields, gardens and } \\
\text { roads close to the river, loss of animals } \\
\text { and, sometimes, of people }\end{array}$ \\
\hline 3 & $\begin{array}{l}\text { Above - average, } \\
\text { regional flood on a } \\
\text { disaster scale }\end{array}$ & $\begin{array}{l}\text { Severe damages on buildings } \\
\text { and constructions related } \\
\text { to the river. In part, some } \\
\text { buildings can be destroyed or } \\
\text { torn away by the river }\end{array}$ & $\begin{array}{l}\text { Severe damages on fields, gardens and } \\
\text { roads close to the river, extensive loss } \\
\text { of animals and people. Morphodynamic } \\
\text { processes cause lasting damages and } \\
\text { changes of the surface structure, } \\
\text { sometimes longer of several days or weeks }\end{array}$ \\
\hline
\end{tabular}



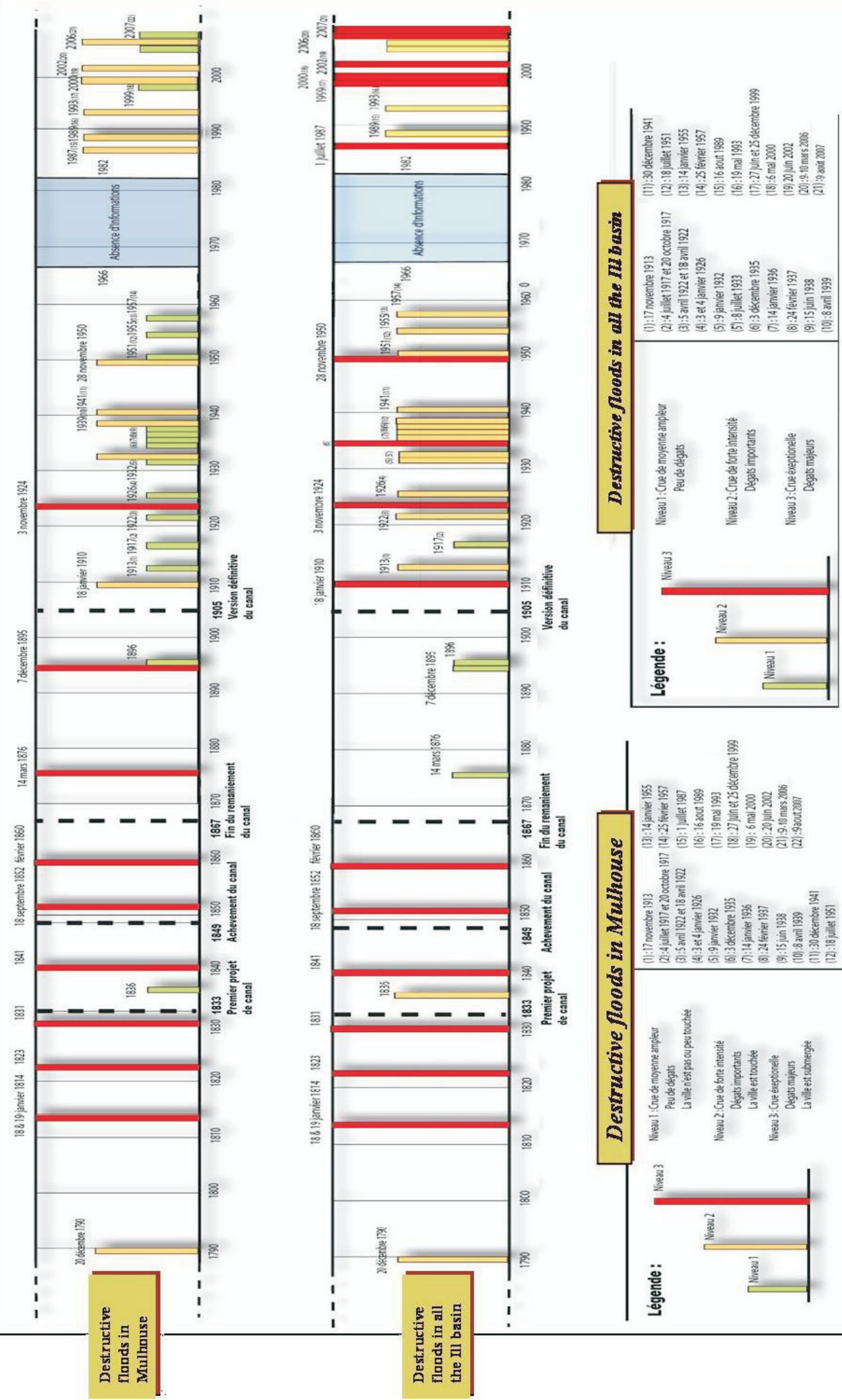

Fig. 5 - Chronology and classification of the floods of the III in Mulhouse (left) and on the whole of the basin (right). 
of the banks of the IIl, whereas in Mulhouse proper the banks have been urbanized and protected for more than a century. Retrospectively, that evolution fully legitimizes the compulsory setting up of a PPRI along the III, and also explains the opposition of some communes to the zoning imposed by the PPRI, as it came mainly from those who had not been able to execute their projects of urbanization close to the river before the endorsement of the PPRI which would render part of the land unfit for building.

Finally, let us note that in August 2007 the first damaging summer flood occurred, a totally new and spectacular event.

\section{Contextualization of the protection afforded by the canal}

If the part played by the diversion canal in the decrease of the damages caused by floods appears as the evident conclusion from the geo-historical study, it is nevertheless necessary to evoke the limits of that analysis, which will lead us to make some reservations about the efficacy, present and future, of the canal, and even to issue a warning about the false sense of security it engenders.

\section{Floods and solidarity between the districts}

First of all, it is important to situate the problem of the protection against the risk of floods within the broader context of the basin of the III as a whole, and particularly the indispensable links of solidarity between upstream and downstream. In fact, and long before the present system of alert against the floods, at the time of the telegraph, a procedure had been set up to inform the inhabitants of Mulhouse of the imminence of a flood. But the "solidarity" extends much further, and people become aware that the diversion canal is only one element of a system of protection that gives priority to the city of Mulhouse on the whole extent of the river basin, sometimes at the detriment of the neighbouring communes. The documents in the archives shows that those situated immediately to the north (Illzach / Sausheim) have thus been "sacrificed" with full knowledge of the fact in the construction of the canal in 1846, which caused a worsening of the floods downstream, due to the elimination of the sewage fields for the excess water in the area of Mulhouse.

What is more, the basin of the Largue, the main tributary of the IIl upstream from Mulhouse, was the object of a PPRI separately prescribed and approved with lightning speed as early as 1997. In the absence of any significant exposition of what was at stake, that PPRI aims primarily at protecting the areas of expansion for the rising water of the Largue, a rather erratic river (129 inundations have been listed since 1700), thus making sure that there is a time lag of six hours betwen the peak of the flood of that river and that of the IIl, and that in consequence the the rising flood has spread out before it reaches Mulhouse downstream (WITH, 2007). The PPRI for the upper basin of the III also protects the areas of expansion of the floods, but in a much more urbanized context, which raises the problem of what is to become of the links of solidarity between downstream and upstream. In fact, as a result of the repeated inundations which in this case affect urbanized districts, there is a considerable increase of the number of requests for the sharing of the damage costs, and, above all, for the building of embankments to cope with the increasing pressure of demography and construction in the Ill valley uphill from Mulhouse. On top of it all, the recent transformation of the agricultural techniques in the higher basin, with the extension of the culture of cereals, maize in particular, are destructive of meadows and forests. All those factors contribute to modify the dynamics of the river (speed of the rise of the waters, decrease of the areas of expansion, acceleration of the flow, etc.), and so the nature of the random effects, with the result that the present risk of inundation is worse than it was in 1905 , and above all in 1983, the year of the reference flood for the basin of the IIl. Mulhouse thus finds itself in a situation of high dependence from the communes of the higher basin of the IIl, and of great uncertainty as to the efficiency of the protection, present and future, afforded by the derivation canal, on account of the modification of the land occupancy.

\section{What we know of the highest floods}

Beside the interdependence between upstream and downstream, there are other reservations to be made as to the protection of the city against the floods of the III. The reference floods (April-May 1983, February 1990) on which the statutory zoning in the PPRI was based, must be treated with caution on two accounts. On the one hand, the recent and spectacular character of those two floods left those in charge of the zoning unmotivated to go further back in time in search of events which could have been even worse. And it is a fact that, in the case of Alsace, to the habitual heavy cost of research in the archives was added the difficulty that the documents were drawn up in German, which was dissuasive for the non-specialist in the language. On the other hand, the elaboration of the model of the centennial flood is based on a short timespan. But the fact of leaving aside older occurences (from the 16th to the 20th century) probably results in the underestimation of the actual level of that centennial flood. The extreme events (Fig. 6) brought to the light by the research carried out on the scale of the Upper Rhine within the framework 


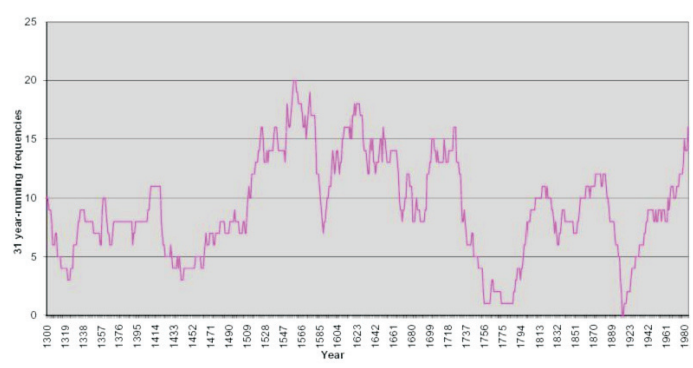

Fig 6 - Temporal dimension of flood occurrence in "Rhin Supérieur" area.

of the Franco-German program TRANSRISK [2], are few and disregarded, but would at least deserve to be taken into account, if not integrated into the zoning, by those in charge of the prevention and management of risks. For the situations of overflooding are often common to the whole of the Fossé Rhénan and the geo-history of 7 centuries of inundations reveals disastrous floods in the Land of Baden next to Alsace (Glaser \& al, 2007). Besides, what of the risk of flood from the Doller? Oddly enough, concerning that first Vosgian river to flow into the III, the procedure for a PPRI was prescribed as early as 1997, but has only just begun to be activated. And yet, its area that is liable to flooding is of prime concern for the city of Mulhouse (Fig. 2, Fig. 4). So, the statutory mapping of the PPRI is a very inadequate representation of the risk of floods, thus generating a deceptive sense of security. One instance of this is that, while the statutory zoning plan indexes "a zone liable to inundation by overflow in the event of a centennial flood, with a moderate level of risk, susceptible of being opened to urbanization", the city of Mulhouse in its information brochure for the public translates it in these terms: "The plan for the prevention of the risks of flood has established a zone liable to be flooded, with a low level of risk, situated on a level with the camping site of the Ill". But does the city deserve to be blamed when the PPRI on the one hand, in its notice of introduction, evokes the catastrophic floods of 1852, 1876, or 1910 (a more than centennial recurrence), but seems to leave them totally out of account in its zoning !

\section{Discussion}

\section{A false perception of mastery and security?}

That impression of mastery and security is further reinforced by the fact that the only damaging floods experienced by Mulhouse in the course of the last decades are due to urban streaming resulting from the gradual extension of the town to the lower foothills of the Sundgau. Is it possible that this urban streaming; frequent, localized, and of moderate impact (even though a natural disaster is decreed) serves to conceal the actuality of a heavy risk of flood? That new peril coming from above (the hills of the Sundgau) takes the place of the traditional peril from below (the river) and makes us oblivious of it (MARTIN; Vitoux, 2003). Besides, the generalized use of the term "disaster" for occurences that are minor and easily "manageable" by those in charge has the perverse effect of inducing people to overestimate the existing capacity to measure and master a real disaster. That effect was made worse by the historical context proper to Alsace. The period of the German occupation between 1870 and 1918 produced sources of archives in German. The difficulty to consult them resulted in the under-exploitation of the information relative to that period, and from that very fact the underestimation, and even the concealment of damaging occurences such as the floods of 1895, 1910 or 1919.

Adoption of a procedure permitting to re-allocate the risks of inundations to the territories

Even though the PPRI marks a real progress in the prevention of risks, one must make it clear once again that its use as an instrument is limited. In Mulhouse, the policy of prevention demands that one should go beyond the prescriptions of the PPRI on the basis of the feedback from the experience of past floods and of the elaboration of scenarios of crisis. If the real level of a flood of centennial recurrence is still to be determined by the pursuit of historical research, the flood of most recent date (August 9, 2007) provides important information. On that occasion, in Mulhouse, what was registered was not the levels to which the waters had risen, but the height of what was left of the embankment, so as to determine the weak spots in case of an exceptionally high flood, and the areas beyond them that were vulnerable and had to be made safe as a matter of priority, particularly in order to prevent the disruption of the tramway and railway networks (MARTIN, 2006), the flooding of spaces open to the public (camping sites, schools etc.). The results will serve to inform and prepare those in charge of the management of the crisis: firemen and civil security, the community of municipalities forming the CAMSA (Communauté d'Agglomération de Mulhouse Sud - Alsace) in charge of the elaboration of a communal plan for safety, and also the Conseil Général of the Department which has an important role to play in the policy of protection and prevention. Lastly, the information will be made available to the public at large through an Internet site with two related objectives. The first is to inform, but also to re-establish the link with the territory through the formation (or recovery) of an 
objective memory of the inundations, in a struggle against oblivion, negation, and ignorance of the risk. The second is to oppose the passiveness and fatalism in a system of risk management which, so far, has tended to emphasize repairs rather than prevention, and, in a way, to weaken the sense of responsability of those who decide.

For one of the fundamental conditions of an effective prevention of risks is to make the local agents responsible for it, and the way is to re-assess the risks in relation to the area and to adapt the statutory zoning to the specific characters of the area and the priorities that derive from them (a "from bottom up" rather than a "from top down" procedure). And what are those priorities? On the basis of of the archives of firemen, an innovating and promising approach (ANSEL, 2008), it was possible to establish that since 1945 no less than 76 inundations have resulted from urban streaming after heavy rainstorms, causing damages in the city of Mulhouse that are moderate, but recurrent, and thus finally of a great cost. And the mapping of them reveals a very different zoning of the risks of inundation (Fig. 7) which should serve to optimize the prevention : diagnosis, the reduction of the chance factor and of the vulnerability, and preparation for the handling of the crisis.

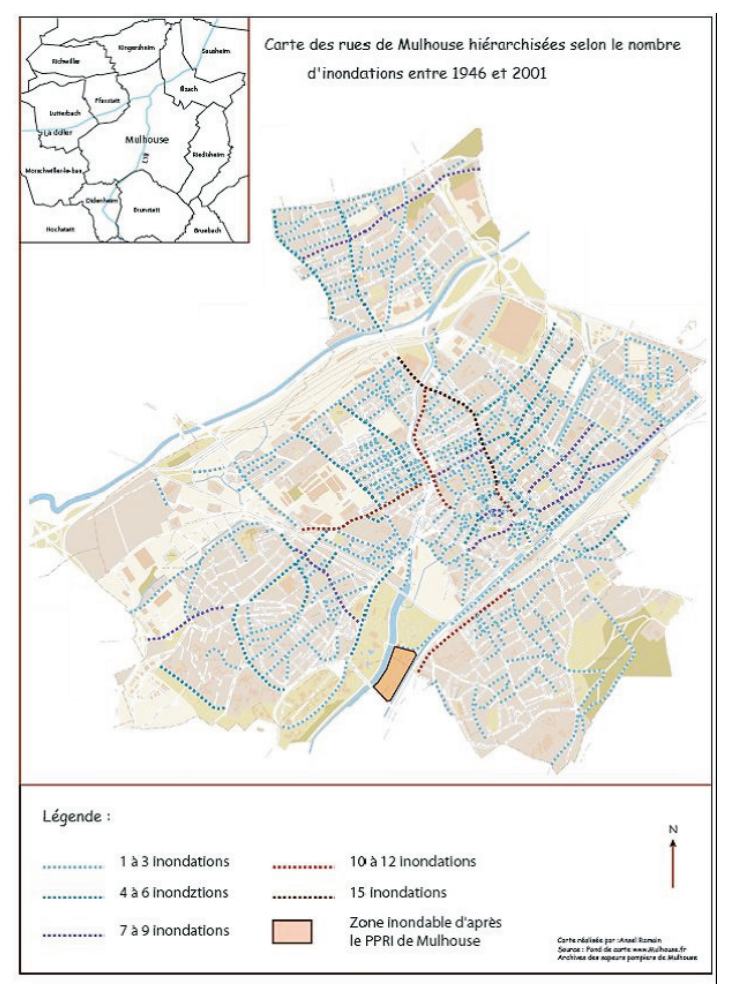

Fig. 7 - Inundations by storm water runoff in Mulhouse between 1946 and 2001.

\section{Conclusion}

The systemic and geo-historical approach proves to be very instructive for the positive evaluation of the efficiency of a work of protection such as the diversion canal of the III at Mulhouse. But it also alerts us to the limits of a work of that kind in the future. The absence of a risk of inundation in the city at the present time, as demonstrated in the zoning of the PPRI, seems to rely on 4 errors of judgement:

- Only the recent events are taken into consideration.

- The extreme phenomena, and those that occurred during the German occupation, are ignored.

- The evolution of the land occupancy upstream has not been integrated.

- Concerning Mulhouse, there has been no adjustment to the reality and the priorities of the risk of inundation, on which the urban streaming has more impact than the fluvial overflow.

And we have not included the possible change in the flow of the river in the context of the climatic warming up (see what occurred in August 2007) and the many pressures that could imperil the precarious balance of the solidarity between upstream and downstream. It follows that it is imperative to carry on with the research, and to alert the decision-makers and other agents on the local scenes to the deceptively reassuring aspect, and even counter-productive effect in terms of prevention, of the PPRI of the IIl at Mulhouse (and no doubt at Colmar and Strasbourg as well). Besides, the Doller, another river flowing through Mulhouse, is still at this time ignored in the procedures of prevention of the floods. Finally, let us point out that the proclamation of a natural disaster from "inundations and mudflow" must be interpreted with great care. There must be a fine analysis of the risks they describe, beyond the generic terminology, and even the term "disaster" must be understood in a very precise sense. The town, as it expands away from the river, occupies the hills of the Sundgau, and thus finds itself confronted with a new type of inundation coming no longer from below (the IIl), but from above. Being frequent and recurrent, that urban flow tends to conceal the real nature of the danger. In that situation, the reconstruction of an objective and contextualized geo-history offers an excellent instrument to make the agents on the local scene of the risk conscious of their responsibility and prepared to manage the crisis (MARTIN, 2007). And the invocation of climatic change to explain the increase of the risk of floods must not be used to put out of mind the major responsibility of the action of men in the modification of the dynamics of the rivers. If the factors that activate the floods are chiefly climatic, those are still strongly influenced by the intervention of the anthropogenic predispositions. 
[1] Voir http://www.prim.net/cgi_bin/citoyen/macommune/ bddrm_detail_commune.php?insee $=68224$

[2] This research programme for $2008-2010$ is subsidized by the Agence Nationale de la Recherche (ANR) and the Deutsche Forschunggemeinschaft (DFG), and conducted by the universities of Mulhouse and Freiburg

\section{References}

ANSEL, Romain (2008) - Le risque d'inondation à Mulhouse aux XIXè et XXè siècles. Mémoire de master d'historie contemporaine, Univ. de Haute - Alsace, Mulhouse, $95 \mathrm{p}$.

GLASER, Rüdiger, \& al (2007) - "Extreme floods of the 19th century in southwest Germany”. La Houille Blanche, $\mathrm{n}^{\circ} 1$ - 2007, Paris, p. 67-73.

Guerrouah, Ouarda; Martin, Brice (2007) - "Apport de la recherche historique pour la prévention des risques d'inondation: cas de l'Ill moyenne". Actes du CRESAT, $\mathrm{n}^{\circ} 4$, CRESAT - UHA Mulhouse, p. 6366 (http://www.cresat.uha.fr/presentation/ plonearticle.2008-12-08.7240336541).

MARTIN, Brice (2006) - "Expertise et risques majeurs: le point de vue du géographe". Droit de l'Environnement, $\mathrm{n}^{\circ} 142$, p. 314-323.

MARTIN, Brice (2007) - "Les réseaux comme espace à risque: les limites de l'approche sectorielle du risque". Actes de la Table-Ronde Rhin Sud, $\mathrm{n}{ }^{\circ}$ 6, CRESAT - UHA Mulhouse, p. 117-129.

MARTIN, Brice; Vitoux, Marie-Claire (2003) - "La ville au risque de la nature, la nature au service de la ville". Annuaire historique de Mulhouse, tome XIV, Mulhouse, p. 73-89.

WITH, Lauriane (2007) - "Gestion et prévention du risque d'inondation: cas du bassin de la Largue". Actes du CRESAT, $\mathrm{n}^{\circ} 4$, CRESAT - UHA Mulhouse, p.67-72 (http://www.cresat.uha.fr/presentation/plonearticle.2008-12-08.7240336541) . 